\title{
The Effect of Dietary Supplementation of Onion and Garlic Husk Powder on Protein, Cholesterol and Fat of Duck Meat
}

\author{
Putri PE, Mangisah I, Suthama N \\ Faculty of Animal and Agriculture Sciences, Diponegoro University, \\ Tembalang Campus, Semarang-50275, Central Java, Indonesia \\ pepratiwiekaputri85@gmail.com
}

\begin{abstract}
Onion and garlic husks contain antioxidant compounds such as allinin, allisin and flavonoid. The compounds are able to decrease fat and cholesterol levels in the body. This study was carried out to determine the effect of feeding onion husk powder (OHP) and garlic husk powder (GHP) on protein, cholesterol and fat content of Mojosari duck meat. The experiment was arranged in a completely randomized design (CRD) and used 168 birds of 4 weeks old male Mojosari ducks. The ducks were divided into 7 treatments and 4 replications (6 ducks each). The treatments were conducted for 4 weeks were as follows: T0 (control diet), T1 (control diet $+3 \%$ OHP), T2 (control diet $+6 \%$ OHP), T3 (control diet $+3 \%$ GHP), T4 (control diet $+6 \%$ GHP) and T5 (control diet + $1.5 \%$ OHP $+1.5 \%$ GHP) and T6 (control diet $+3 \%$ OHP $+3 \%$ GHP). The results showed that dietary OHP and GHP significantly increased protein and decreased cholesterol contents of duck meat, but no effect on meat fat. It could be concluded that the effect of feeding of OHP and GHP separately or in combination was able to increase protein and decrease cholesterol contents, but could not decrease fat content of Mojosari duck meat.
\end{abstract}

Key Words: Onion and Garlic Husks, Meat Protein, Cholesterol and Fat, Mojosari Duck

\section{INTRODUCTION}

In 2014, more than 36.9 tons of duck meats were consumed by Indonesian people, equal to $1.24 \%$ of the total national meat production (Ministry of Agriculture 2015). The problem of duck meat was high in fat and cholesterol contents which reached up to $13.8 \%$ and $75 \mathrm{mg}$, respectively (Dean 1978) compared with those of broiler meat which were about $4.97 \%$ and $52.44 \mathrm{mg}$, respectively for fat and cholesterol (Purwanti 2008). Fat and cholesterol are substances that can affect people's health such as caused coronary heart disease, obesity and hypertension if consume in excess amounts. Therefore, it is necessary to create innovations through feed manipulation to decrease fat and cholesterol contents of duck meat.

In recent years, the people have known the health benefits of garlic and onion compounds and made it to be a herbal product. In 2014, Indonesian onion production was 1.227.838 tons with an average growth production was $21.48 \%$ per year while the production of garlic in 2014 was about 16.902 tons with an average growth production was $7.21 \%$ per year (Ministry of Agriculture 2015). Garlic in one kilogram produced about 760 $\mathrm{g}$ of bulb and $240 \mathrm{~g}$ of husk (Qureshi et al. 1983). The husk may contain active substantial compounds such as polyphenol and flavonoid.

Onion (Allium ascalonicum) and garlic (Allium sativum) are herbal ingredients that contains the active substance to be able decrease fat and cholesterol. Both onion and garlic contain allinin and allicin, which are known to be hypolipidemic and other active substances such as flavonoid, quercetin, pectin allyl propyl disulfide (Jaelani 2007). Research of Kim et al. (2009) showed that additional 4\% of garlic husk powder decreased more effective meat cholesterol than the similar percentage garlic bulb powder did in broiler chicken. Ao et al. (2011) stated that addition of fermented onion powder was able 
to increase the quality of meat such as decreasing cholesterol level. Some studies above indicated the possibility of decreasing meat fat and cholesterol levels by supplementing onion husk powder (OHP) and garlic husk powder (GHP) in the duck ration.

This study was carried out to determine the effect of additional onion husk powder (OHP) and garlic husk powder (GHP) on fat, cholesterol and protein contents of duck meat.

\section{MATERIAL AND METHODS}

A total of 168 ducklings of 4 weeks old male Mojosari ducks with an average weight of $369 \mathrm{~g}$ were used for this study. They were fed diet composed of corn, soybean meal, rice bran and fish meal supplemented with OHP and GHP (Table 1). Onion and garlic husks were collected from traditional market in Semarang, Central Java, Indonesia. Onion and garlic husks were dried under sunlight and powdered by grinder (Kim et al. 2009). The ducks were housed in groups under open house system in 28-unit postal cages with 6 individuals per unit.

Table 1. Composition and nutritional content of the experimental diet

\begin{tabular}{|c|c|c|c|c|c|c|c|}
\hline \multirow{2}{*}{ Feed stuff } & T0 & $\mathrm{T} 1$ & $\mathrm{~T} 2$ & $\mathrm{~T} 3$ & $\mathrm{~T} 4$ & T5 & T6 \\
\hline & \multicolumn{7}{|c|}{ 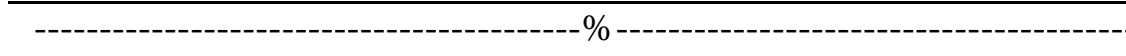 } \\
\hline Corn & 44.50 & 44.50 & 44.50 & 44.50 & 44.50 & 44.50 & 44.50 \\
\hline Soybean meal & 24.00 & 24.00 & 24.00 & 24.00 & 24.00 & 24.00 & 24.00 \\
\hline Fish meal & 10.00 & 10.00 & 10.00 & 10.00 & 10.00 & 10.00 & 10.00 \\
\hline Rice bran & 19.20 & 19.20 & 19.20 & 19.20 & 19.20 & 19.20 & 19.20 \\
\hline $\mathrm{CaCO}_{3}$ & 1.30 & 1.30 & 1.30 & 1.30 & 1.30 & 1.30 & 1.30 \\
\hline Premix & 1.00 & 1.00 & 1.00 & 1.00 & 1.00 & 1.00 & 1.00 \\
\hline OHP & - & 3.00 & 6.00 & - & - & 1.50 & 3.00 \\
\hline GHP & - & - & - & 3.00 & 6.00 & 1.50 & 3.00 \\
\hline Total & 100.00 & 103.00 & 106.00 & 103.00 & 106.00 & 103.00 & 106.00 \\
\hline Crude protein $(\%)$ & 20.06 & 19.68 & 19.32 & 19.67 & 19.31 & 19.68 & 19.32 \\
\hline Ether extract (\%) & 2.95 & 2.94 & 2.93 & 2.93 & 2.90 & 2.94 & 2.92 \\
\hline Crude fiber $(\%)$ & 4.45 & 5.31 & 6.12 & 5.30 & 6.09 & 5.30 & 6.11 \\
\hline $\begin{array}{l}\text { Metabolizable } \\
\text { energy }(\mathrm{kcal} / \mathrm{kg})\end{array}$ & 2902.00 & 2881.00 & 2861.00 & 2884.00 & 2867.00 & 2882.00 & 2864.00 \\
\hline
\end{tabular}

The ducks were fed 3 times a day for 1 month of treatment with the amount of feed was based on the amount of feed consumed by the duck (Supriyadi 2011), their rearing duration was 30 days. Body weight was measured once a week. The experiment was designed to be completely randomized design (CRD) with 7 treatment groups and 4 replicates. Dietary treatments were as follows: T0 (control diet), T1 (control diet $+3 \%$ OHP), T2 (control diet $+6 \%$ OHP), T3 (control diet $+3 \%$ GHP), T4 (control diet $+6 \%$ GHP) and $\mathrm{T} 5$ (control diet $+1.5 \% \mathrm{OHP}+1.5 \% \mathrm{GHP}$ ) and T6 (control diet $+3 \% \mathrm{OHP}+$ $3 \% \mathrm{GHP}$ ). At day 30, prior to slaughtering, the ducks were weighed, feed deprived for $6 \mathrm{~h}$ and then slaughtered in a commercial slaughterhouse. The carcasses were prepared by removing the skin, feet, reproductive organs, and digestive tract. Meat was collected $24 \mathrm{~h}$ postmortem from the carcass and immediately frozen at $-20^{\circ} \mathrm{C}$ until analyzed. 
The parameters measured were fat, cholesterol and protein contents of duck meat. Protein content of meat was analyzed by Kjehldal method, and fat content was measured used soxhlet extraction method and cholesterol content of meat was analyzed according to Liebermann - Burchard method (AOAC 1995). The data was subjected to ANOVA and continued to Duncan multiple test at $\mathrm{P}<0.05$ when the treatment indicated significant affect (Steel \& Torrie 1994).

\section{RESULTS AND DISCUSSION}

\section{Fat content of duck meat}

Meat fat content was not significantly different (Table 2). It can be assumed that the active compounds of garlic had more affect than onion did. According to Rofiq (2003), that high fiber could reduce fat level. Onion and garlic husks had a high crude fiber content about $33.85 \%$ and $33.41 \%$ respectively. Slightly decreasing level of fat, it could also decrease the cholesterol level. The amount of feed intake would affect the growth of high fat and consequently ended up with high accumulation of cholesterol in meat.

The formation of body fat in duck was due to an excess of energy consumed. According to the North \& Bell (1990) energy from feed stuff was used by animal for maintenance, growth (including fats) and production. Syukron (2006) stated that the high amount of diet caused the increase fat meat. The high amount of feeding crude fiber, led to decrease meat fat content, because more energy was needed to digest feed crude fiber, consequently there was no storage of excess energy.

Table 2. Protein, fat and cholesterol meat of 8-weeks old Mojosari duck

\begin{tabular}{lccccccc}
\hline \hline \multirow{2}{*}{ Variable } & \multicolumn{7}{c}{ Treatment } \\
\cline { 2 - 8 } & T0 & T1 & T2 & T3 & T4 & T5 & T6 \\
\hline Meat fat (\%) & $23.21^{\text {ns }}$ & $22.19^{\text {ns }}$ & $22.71^{\text {ns }}$ & $21.56^{\text {ns }}$ & $22.56^{\text {ns }}$ & $22.85^{\text {ns }}$ & $21.23^{\text {ns }}$ \\
Meat cholesterol & $45.67^{\mathrm{a}}$ & $32.61^{\mathrm{c}}$ & $28.65^{\mathrm{d}}$ & $28.60^{\mathrm{d}}$ & $37.42^{\mathrm{b}}$ & $38.98^{\mathrm{b}}$ & $28.59^{\mathrm{d}}$ \\
(mg/100 g) & & & & & & & \\
Meat protein $(\%)$ & $19.88^{\mathrm{d}}$ & $21.52^{\mathrm{abc}}$ & $20.51^{\text {cd }}$ & $20.81^{\mathrm{bcd}}$ & $21.13^{\mathrm{abcd}}$ & $21.94^{\mathrm{ab}}$ & $22.52^{\mathrm{a}}$ \\
\hline
\end{tabular}

- ns: non significant

- Different small letters indicate significant difference at 5\% levels in the same row

\section{Cholesterol content of duck meat}

Meat cholesterol was significantly affected by treatments (Table 2). Control diet produced the highest cholesterol meat content but T6 was the lowest similar to those of T2 and T3 (Table 2). However, T1, T4 and T5 were medium level although among them were significant. This was because of the onion and garlic husks had antioxidants content such as allicin, polyphenols and flavonoid. Antioxidant activity of OHP was about 50.43 ppmand GHP was about 1754.88 ppm respectively. The antioxidant activity can increase the production and secretion of bile therefore could aid to breakdown of fat and decrease cholesterol synthesis, because more bile was secreted, more cholesterol was used in the production of bile. The present result was in accordance the finding of Kim et al. (2009) that the garlic powder and garlic extract have shown antioxidant activity in different types of poultry meat. The production of bile will be secreted and used for fat metabolism. A product of the fat metabolism was in the form of bile acids and these bile salts were 
reabsorbed while the results in the form of cholesterol wasted in excreta. Thereby, it could decrease cholesterol level. Sujana et al. (2007) reported that the reduction of cholesterol meat occurs as a result of blood cholesterol in the body was widely used to synthesize bile. Gong-chen et al. (2014) stated that cholesterol absorption in the small intestine could be inhibited by saponin (component in allicin), saponin might also reduce plasma cholesterol level.

In addition to antioxidant content in the onion and garlic husks, the fiber content also capable to decrease cholesterol in the body of duck. Fibers are being mediator to increase bile acids excretion to decrease cholesterol. The mechanism of cholesterol synthesis suppression induced by dietary crude fiber was to increase intestinal peristaltic caused feed was not absorbed optimally. This phenomenon decrease basic compounds as precursor of cholesterol in blood vessel and tissue also reproduce lost bile salts in the duodenum so that hearts need more cholesterol to produce bile salts by taking up cholesterol in the tissue (Astuti 2004). According to Devlin et al. (1993) cholesterol was part of a fat. If the amount of fat content in the body was low, the cholesterol would be as low as fat content. This was consistent with the results of present study that the lowest fat and cholesterol duck meat levels was found in T3 and T6.

\section{Protein content of duck meat}

Meat protein was significantly affected by treatments (Table 2). Control diet caused the lowest content of meat protein but T6 was the highest. According to Hartono et al. (2013) stated that fat content has a negative correlation with protein content, slightly increasing the protein duck meat content, it can also decrease the fat content of meat. This was evident from this research data that meat with high protein content and low fat content found on T6.

Antioxidant content in onion and garlic can act as an antibacterial that can improve the health of the digestive system therefore absorption of nutrients diet will be increased. One indication of good absorption of nutrient is the result of protein digestibility. Protein digestibility values were not significantly different. The value of protein digestibility although statistically was not different, T6 and T4, numerically were slightly higher than the others (Yoseph unpublished). The high amount of protein digestibility caused the amount of nitrogen that enters to the body increased, so that the process of protein synthesis increased and produced high protein content of meat. Winedar et al. (2004) stated that one factor that affected the chemical composition of meat was good feed absorption; it needed to be supported by digestive enzymes to remodel a feed nutrient into smaller molecules that could facilitate absorption and therefore affected growth. The content of onion husk was also able to inhibit the growth of bacteria (Escherichia coli, Pseudomonas fluorescens and Bacillus cereus) and fungi (Aspergillus niger, Trichoderma viride and Penicillium cyclopium) (Skerget et al. 2009).

\section{CONCLUSION}

Feeding onion and garlic husks powder separately or in a combination was able to decrease cholesterol meat content and increased protein meat content but no effect on fat content of Mojosari male duck meat.

\section{ACKNOWLEDGEMENT}

This project was supported by PT Indofood Sukses Makmur, Tbk. through the Indofood Research Nugraha Program, 2015. 


\section{REFERENCES}

Ministry of Agriculture. 2015. The strategic plan of agriculture ministry period 2015-2019. Jakarta (Indonesia): Agriculture Ministry of Republic Indonesia.

Ao X, Yoo JS, Zhou TX, Wang JP, Meng QW, Yan L, Cho JH, Kim IH. 2011. Effects of fermented garlic powder supplementation on rowth performance, blood profiles and breast meat quality in broilers. J Livest Sci. 141:85-89.

AOAC. 1995. Official methods of analysis of AOAC International. 2 vols. 16th edition. Arlington (USA): Association of Analytical Communities.

Astuti. 2004. Utilization of fish waste starch in the diet on cholesterol levels of broiler meat. Proceeding Seminar of Mathematic and Nature Sciences, Muhammadiyah Yogyakarta University.

Dean WF. 1978. Nutrient requirements of ducks. Proceedings 1978 Cornell nutrition conference for feed manufacturers. October 31, November 1, 2, 1978, Sheraton Motor Inn, Syracuse, New York. Ithaca (USA): Cornell University. p. 132-140.

Devlin MT. 1993. Texbook of biochemistry with clinical correlations. Third edition. New York (USA): Wiley-Liss. p. 438-442.

Gong-chen W, Lu-lu H, Jing W, Wan-nan L, Chuan-yi P, Yan-fei L. 2014. Effects of allicin on lipid metabolism and antioxidant activity in chickens. J North Agric Univ. 21:46-49.

Hartono E, Iriyanti N, Santosa R, Singgih S. 2013. The use of functional feed on tie against water, cooking losses, and tenderness of meat broiler. J Ilmu Peternakan. 1:10-19.

Jaelani. 2007. Khasiat bawang merah (The effectiveness of onion). Yogyakarta (Indonesia): Kanisius.

Kim YJ, Jim SK, Yang HS. 2009. Effect of dietary garlic bulb and husk on the physicochemical properties of chicken meat. Poult Sci. 88:398-405.

North MO, Bell DD. 1990. Commercial chicken production manual. 4th ed. New York (USA): Chapman and Hall.

Purwanti S, Mutia R, Widhyari SD, Winarsih W. 2008. Kajian efektifitas pemberian kunyit, bawang putih dan mineral zink terhadap performa, kolesterol karkas dan status kesehatan broiler. Dalam: Sani Y, Martindah E, Nurhayati, Puastuti W, Sartika T, Parede L, Anggraeni A, Natalia L, penyunting. Inovasi teknologi mendukung pengembangan agribisnis peternakan ramah lingkungan. Prosiding Seminar Nasional Teknologi Peternakan dan Veteriner. Bogor, 11-12 November 2008. Bogor (Indonesia): Puslitbang Peternakan. p. 690-695.

Qureshi AA, Abuimeileh N, Din ZZ, Elson CE, Burger WC. 1983. Inhibition of cholesterol and fatty acid biosynthesis in liver enzymes and chicken hepatocytes by polar fractions of garlic. Lipids. 18:343-348.

Rofiq MN. 2003. Pengaruh pakan berbahan baku lokal terhadap performans vili usus halus ayam broiler. J Sains dan Teknologi Indonesia. 5:190-194.

Skerget M, Majhenie L, Bezjak M, Knez Z. 2009. Antioxidant, radical scavenging and antimicrobial activities of red onion (Allium cepa L.) skin and edible part extracts. Chem Biochem Eng. Q. 23:435-444.

Steel GD, Torrie JH. 1994. Principles and procedures of statistics. Jakarta (Indonesia): Gramedia Pustaka Utama.

Sujana E, Darana S, Garnida D, Widjastuti T. 2007. Efek Pemberian Ransum Mengandung Tepung Buah Mengkudu (Morinda citrifolia Linn.) terhadap Kandungan Kolesterol, Persentase Karkas dan Lemak Abdominal Ayam Broiler. Dalam: Darmono, Wina E, Nurhayati, Sani Y, Prasetyo LH, Triwulanningsih E, Sendow I, Natalia L, Priyanto D, Indraningsih, Herawati T, penyunting. Akselerasi agribisnis peternakan nasional melalui pengembangan dan penerapan IPTEK. Prosiding Seminar Nasional Teknologi Peternakan dan Veteriner. Bogor, 21-22 Agustus 2007. Bogor (Indonesia): Puslitbang Peternakan. p. 556-561. 
Supriyadi. 2011. Panen itik pedaging dalam 6 minggu. Jakarta (Indonesia): Penebar Swadaya.

Syukron M. 2006. Kandungan lemak dan kolesterol daging serta persentase organ dalam ayam broiler yang diberi ransum finisher dengan penambahan kepala udang. [Thesis]. [Bogor (Indonesia)]: Institut Pertanian Bogor.

Winedar, Hanifiasti, Listyawati S, Sutarno. 2004. Digestibility protein of feed, meat protein content and weight gain after feeding with fermented feed with effective microorganisms -4 (EM-4) on broiler. J Biol. 3:14-19. 